\title{
Increasing dietary crude protein levels attenuates the effects of caecotrope deprivation in growing rabbits
}

\author{
S.A. Salami ${ }^{1 *}$, O.O. Adelusi ${ }^{2}$, O.A. Isah ${ }^{2}$, R.Y. Aderinboye ${ }^{2}$ and L.O. Ajayi ${ }^{3}$ \\ ${ }^{1}$ National Biotechnology Development Agency, Airport Road, Lugbe, \\ Federal Capital Territory Abuja Nigeria \\ ${ }^{2}$ Department of Animal Nutrition, Federal University of Agriculture Abeokuta P.M.B. 2240, \\ Ogun State, Nigeria. \\ ${ }^{3}$ Department of Veterinary Patholology, Federal University of Agriculture Abeokuta P.M.B. 2240, \\ Ogun State, Nigeria. \\ *Corresponding E-mail :salami.suliata@pg.funaab.edu.ng
}

Received March 16, 2021; Accepted September 10, 2021

\begin{abstract}
ABSTRAK
Pengaruh kekurangan caecotrope pada pertumbuhan, metabolisme sekum dan produksi asam lemak volatil (VFA) dipelajari pada kelinci yang diberi berbagai tingkat protein pakan selama percobaan makan 42 hari. Empat puluh delapan kelinci ras campuran (berat awal rata-rata $=875 \pm 25 \mathrm{~g}$ ) dibagi menjadi dua kelompok yaitu; kelompok pemakan caecotrope (CC) dan caecotrope-deprived (CD). Kelinci terbagi dalam 2 kelompok dan masing-masing kelompok diberikan 3 ransum yang mengandung kadar protein kasar (CP) yang berbeda (12, 15 dan 18\%) dalam pengaturan faktorial $2 \times$ 3. Hasilnya menunjukkan bahwa peningkatan $\mathrm{CP}$ diet meningkatkan $(\mathrm{P}<0,05)$ caecotrope. Bobot hidup, pertambahan berat badan, rasio konversi pakan, pemanfaatan nitrogen dan produksi VFA pada kelinci $\mathrm{CD}$ yang diberi pakan yang mengandung $18 \% \mathrm{CP}$ sebanding $(\mathrm{P}<0,05)$ dengan pakan yang diberi $\mathrm{CC}$ dengan $15 \%$ CP. Pemanfaatan nitrogen meningkat $(\mathrm{P}<0,05)$ mengikuti peningkatan kadar protein kasar pakan. Proporsi molar asetat, butirat, dan propionat lebih tinggi $(\mathrm{P}<0,05)$ pada kelinci $\mathrm{CC}$ dibandingkan dengan CD. Lactobaccilus acidophilus diisolasi dari sekum kelinci CC. Disimpulkan bahwa kekurangan caecotrope memiliki efek merugikan pada pertumbuhan, metabolisme nitrogen, produksi VFA dan bakteri sekum. Efek ini dapat dikurangi dengan meningkatkan tingkat protein pakan pada kelinci yang sedang tumbuh.

Kata kunci: Caecotrope, Penggunaan protein bakteri sekum, Fermentasi sekum, Asam lemak volatil
\end{abstract}

\section{ABSTRACT}

The effect of caecotrope deprivation on growth, caecal metabolism and Volatile Fatty acid (VFA) production was studied in rabbits fed varying levels of dietary protein during a 42-days feeding trial. Fourty-eight mixed breed rabbits (average initial weight $=875 \pm 25 \mathrm{~g}$ ) were divided into two 
groups viz; caecotrope consuming (CC) and caecotrope-deprived (CD) groups. Rabbits in the 2 groups were divided equally and assigned to 3 diets containing different crude protein (CP) levels $(12,15$ and $18 \%$ ) in a $2 \times 3$ factorial arrangement. The result revealed that increasing dietary CP improved $(\mathrm{P}<0.05)$ the proximate composition of the caecotrope. The live weight, weight gain, feed conversion ratio, nitrogen utilization and VFA production in $\mathrm{CD}$ rabbits fed diets containing $18 \% \mathrm{CP}$ were comparable $(\mathrm{P}<0.05)$ with those of $\mathrm{CC}$ fed diets with $15 \% \mathrm{CP}$. Nitrogen utilization increased $(\mathrm{P}<0.05)$ following increasing dietary crude protein level. Molar proportions of acetate, butyrate, and propionate were higher $(\mathrm{P}<0.05)$ in $\mathrm{CC}$ rabbit compared to $\mathrm{CD}$. Lactobaccilus acidophilus was isolated from the caecum of $\mathrm{CC}$ rabbits. It was concluded that caecotrope deprivation has detrimental effect on growth, nitrogen metabolism, VFA production and caecal bacteria and this effect can be attenuated by increasing the dietary protein level in growing rabbits

Keywords: Caecotrope, Caecal bacteria protein utilization, Caecal fermentation, Volatile fatty acid.

\section{INTRODUCTION}

The practice of caecotrophy (soft faeces consumption) is one of the most important characteristics of the digestive physiology of the rabbit. It is the strategy the rabbit employs to improve nutrient digestibility and allow maximal utilization and absorption of total ingested nutrients (Tham and Uden, 2013). Caecotropes are packets of partially digested feed, bacteria and bacterial products (including vitamins) eaten directly from the anus (Meredith, 2011). They also contain many microorganisms, which are important for microbial fermentation and the proper functioning of the gut microflora (Kujawinski 2012). Hence, a disorder in the caecotrophy behaviour may have far-reaching consequences on the health and welfare of the rabbit (Wang et al., 2019).

Previous researches (Phiny and Kaensombath, 2006; Wang et al., 2019: Salami et al., 2021) have demonstrated that, caecotrope deprivation leads to malnutrition and reduced growth performance, feed efficiency, lipid synthesis and survivability in the rabbit. It is therefore pertinent that when conditions such as stress, anal injury, sickness and diet imbalance occur, and the rabbit is unable to eat its caecotropes, measures that can cushion the attendant negative consequences must be put in place.

Dietary modification could be a major way of attenuating the negative effects associated with caecotrope deprivation. This is because the rabbit's caecum has the ability to ferment easily available substrate (from any source) for microbial synthesis and protein recycling (Villamide et al., 2010). Suffice to say that an increase in the levels of available nutrients in the caecum, results in a corresponding increase in the flow of substrates to the fermentative area (de Blas, 2013). Caecotrope deprived rabbits may then be able to make up for lost nutritional benefits by raising the nutrients in diets above recommended levels. However, there exists relatively few known studies on the role of diet in ameliorating the negative effects of caecotrope deprivation in rabbits. Hence, this research aims to determine the effects of increasing dietary protein levels on the growth performance, caecal metabolism and caecal bacteria in caecotropedeprived rabbits.

\section{MATERIALS AND METHODS}

\section{Experimental Location}

This study was carried out at the teaching and Research Farm of the Federal University of Agriculture, Abeokuta, Nigeria $\left(7^{\circ} 9^{\prime} 20.56 " \mathrm{~N}, 3^{\circ}\right.$ $\left.20^{\prime} 42.32^{\prime \prime E}\right)$. This lies in the tropical climate with average annual rainfall of $1100 \mathrm{~mm}$ and annual mean temperature of $34^{\circ} \mathrm{C}$ and $80 \%$ relative humidity.

\section{Experimental Procedure}

A total of forty-eight, 8-week-old mixed breed rabbits with an average initial live weight of $875 \pm 25 \mathrm{~g}$ were housed individually in wellventilated stainless steel welded mesh cages (hutches measuring $0.85 \times 0.65 \times 0.50 \mathrm{~m}$ in dimension) fitted with feeders and waterers and kept inside well ventilated shed with cemented floor, under controlled light cycle $(12 \mathrm{~h}$ light/ $12 \mathrm{~h}$ dark). Three isocaloric and iso-fibrous diets with varying crude protein levels $(12,15$, and $18 \%)$ 
were formulated (Table 1) based on the recommendations for minimum and maximum dietary crude protein requirement in grower's mash (de Blas and Mateos., 2010).

After a 7-day acclimatization period, the rabbits were divided into two groups namely caecotrope consuming (CC) and caecotropedeprived (CD) groups. Rabbits in the $\mathrm{CD}$ group were prevented access to their caecotrope with the aid of the plastic neck collar. The flat collar was made out of rigid polypropylene $(2 \mathrm{~mm}$ thick). The mean external diameter averaged $25.0 \mathrm{~cm}$ and weighed $50 \mathrm{~g}$ as described by Gidenne and Lapanouse (2000). The two groups of rabbits were randomly assigned to 3 diets containing different crude protein levels $(12,15$ and $18 \%$ ) in a $2 \times 3$ factorial arrangement. The 6 treatment groups consisted of 8 rabbits each, in a completely randomized design. Feed and water were offered ad libitum throughout the experimental period. that lasted 42 days.

\section{Sample Collection}

During the last 7 days of the trial, 3 rabbits per treatment (18 rabbits in all) were randomly selected from each treatment and confined to metabolism cages for the total collection of faeces and urine. Rabbits were individually housed in cages that permit the partition of feces and urine. An acclimatization period of 3 days was allowed prior to the total collection of samples, which lasted 4 days. The rabbits were given a known weight of feed throughout the metabolic trial. Hard feces and caecotropes were collected and weighed. Urine was collected individually in clean bottles under $1 \mathrm{M} \mathrm{H}_{2} \mathrm{SO}_{4}(50 \mathrm{ml} / \mathrm{L}$, final $\mathrm{pH}<3$ ). Urine sample was weighed, diluted (to 1 $\mathrm{L})$, sampled $(100 \mathrm{~mL})$ and stored at $-20^{\circ} \mathrm{C}$ till required for analysis. The proximate composition in feeds and feces and nitrogen content of urine was determined according to AOAC (2005).

On day 42 of the experiment, 5 rabbits per treatment (30 rabbits in all) were slaughtered by cervical dislocation, dissected and the caecum excised and weighed. Caecal content $\mathrm{pH}$ was measured with a glass electrode $\mathrm{pH}$-meter. Immediately afterwards, two samples of caecal contents were taken ( $1 \mathrm{~g}$ each), acidified with either $0.2 \mathrm{M} \mathrm{HCl}$ or $0.5 \mathrm{M} \mathrm{H}_{3} \mathrm{PO}_{4}$ and both stored at $20^{\circ} \mathrm{C}$ for ammonia and volatile fatty acid (VFA) determination, respectively. The remaining cae-

Table 1. Ingredients $(\mathrm{g} / \mathrm{kg})$ and Chemical Composition $(\mathrm{g} / \mathrm{kg} \mathrm{DM})$ of the Experimental Diets

\begin{tabular}{|c|c|c|c|}
\hline & Diet 1 & Diet 2 & Diet 3 \\
\hline \multicolumn{4}{|l|}{ Ingredient (g/kg) } \\
\hline Maize & 280.00 & 250.00 & 270.00 \\
\hline Soya bean meal & 100.00 & 170.00 & 180.00 \\
\hline Fish meal $(72 \% \mathrm{CP})$ & 0.00 & 0.00 & 10.00 \\
\hline Wheat offal & 300.00 & 260.00 & 300.00 \\
\hline Rice husk & 150.00 & 140.00 & 200.00 \\
\hline Maize offal & 130.00 & 140.00 & 0.00 \\
\hline Oyster Shell & 15.00 & 15.00 & 15.00 \\
\hline Bone meal & 15.00 & 15.00 & 15.00 \\
\hline Vitamin premix & 5.00 & 5.00 & 5.00 \\
\hline Salt $(\mathrm{NaCl})$ & 5.00 & 5.00 & 5.00 \\
\hline Total & 1000.00 & 1000.00 & 1000.00 \\
\hline \multicolumn{4}{|l|}{ Determined by Analysis: } \\
\hline Dry matter $(\%)$ & 89.90 & 88.15 & 90.23 \\
\hline Metabolizable Energy (Kcal/kg) & 2500.00 & 2500.00 & 2500.00 \\
\hline Crude protein $(\%)$ & 12.35 & 14.95 & 18.88 \\
\hline Crude fibre $(\%)$ & 7.85 & 7.31 & 7.96 \\
\hline Ash $(\%)$ & 10.04 & 10.52 & 10.06 \\
\hline Ether extract (\%) & 4.45 & 4.09 & 4.68 \\
\hline Dry matter $(\%)$ & 89.90 & 88.15 & 90.23 \\
\hline \multicolumn{4}{|c|}{ 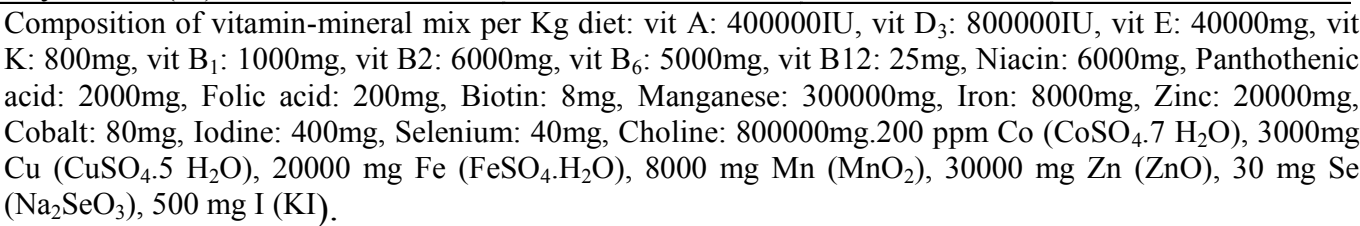 } \\
\hline
\end{tabular}


cal contents were weighed (20 to $50 \mathrm{~g}$ ), diluted in a methylcellulose solution $(9 \mathrm{~g} \mathrm{NaCl} / \mathrm{L}, 1 \mathrm{~g}$ methylcellulose/L) and chilled at $4^{\circ} \mathrm{C}$ for $24 \mathrm{~h}$ to dislodge and isolate adherent bacteria as previously described (Belenguer et al., 2005).

Nitrogen $(\mathrm{N})$ was measured by the Kjeldhal method. Total VFA concentrations of caecal content were measured by steam distillation technique according to Eadie et al. (1967) while molar percentages of propionic, acetic and butyric acids were determined by using Gas- liquid chromatography (Samuel et al., 1997). Caecal $\mathrm{NH}_{3}-\mathrm{N}$ concentrations were measured by spectrophotometry according to Chaney and Marbach (1962).

The bacteria isolated were identified using morphological culture characteristics i.e., colour, consistency, shape, size, elevation, edge, opacity and biochemical test (such as oxalate, citrase, catalase, e.t.c.). Bacteria were identified based on the result obtained from biochemical characterization.

\section{Statistical Analysis}

Data were analyzed by ANOVA as a complete randomized design, following a $2 \times 3$ factorial arrangement, with caecotrope deprivation as factor and dietary crude protein $(12 \%, 15 \%$ and $18 \%)$ as level. Data were analyzed using the using the General Linear model procedure of the statistical software SAS (2004). The level of statistical significance was set at $\mathrm{P}<0.05$.

\section{Ethics Approval}

"All applicable international, national, and/or institutional guidelines for the care and use of animals were followed. In line with the ethics regulations stated in the Guide for the Care and the Use of Laboratory Animals prepared by the National Academy of Science (NRC, 2011). The research group ensured all the rats received humane care throughout the period of the study

\section{RESULTS AND DISCUSSION}

\section{Effects of dietary protein levels on the proxi- mate composition of soft faeces}

Table 2 revealed that the Dry matter (DM), CP, ash and ether extract content of the soft feces increased $(\mathrm{P}<0.05)$ following increasing CP level in the diet. This observation is in line with the findings of Rodríguez-Romero et al. (2011) who reported that dietary fibre compo- sition is correlated with the crude protein content of the caecotropes. This finding may be due to the extra nutrients (protein) supply which might have promoted a higher microbial activity and consequently nutrient recycling in soft faeces (García et al., 2002). The rabbit caecum ferments easily available substrate for microbial synthesis and protein recycling (Villamide et al., 2010)

\section{Growth Performance}

The trend in result on Table 3 revealed that performance index in $\mathrm{CD}$ rabbits fed diets containing 12 and $15 \% \mathrm{CP}$ were poorer $(\mathrm{P}<0.05)$ than those of their CC counterparts. The negative effect of caecotrope deprivation seen in the current study may be due to lesser absorption of vitamins and essential amino acids in microbial cells (Wang et al., 2019). On the other hand, CC rabbits on $15 \%$ CP had performance index similar to those of $\mathrm{CD}$ rabbits fed diet containing $18 \% \mathrm{CP}$. This observation suggests that, feeding crude protein above recommended levels may be beneficial in attenuating the negative effect of caecotrope deprivation on growth and feed utilization. In comparison to rabbits on other dietary treatment, $\mathrm{CD}$ rabbits fed diet containing $12 \%$ $\mathrm{CP}$ had the highest $(\mathrm{P}<0.05)$ mortality rate. This suggests that the negative effect of caecotrope deprivation is more pronounced under poor dietary conditions. Higher mortality resulting from poor diet could be explained by the fact that caecotrope deprivation reduces the population of intestinal bacteria. This has negative consequences on metabolism, immune system development, disease resistance and other physiological functions necessary for the health and survivability of the rabbit (Heinken et al., 2013; Goto et al., 2015). Reduced mortality rate seen in CD rabbits fed diets containing $18 \% \mathrm{CP}$ suggests that an extra supply of dietary protein might be necessary for attenuating the negative consequences of caecotrope deprivation on intestinal flora.

\section{Nitrogen Utilisation}

Results on Table 3 revealed that caecotrope consumption and increasing dietary crude protein level significantly $(\mathrm{P}<0.05)$ affected the nitrogen intake, nitrogen absorption and nitrogen retention. The nitrogen intake, percentage nitrogen absorbed and retained increased $(\mathrm{P}<0.05)$ following increasing levels of dietary $\mathrm{CP}$ in $\mathrm{CD}$ rabbits. This observation agrees with the findings of Jegsai et al. (1985) who reported that the effect of caecotrophy on protein and amino acid 
Table 2. Effects of Dietary Crude Protein Level on the Proximate Composition of Caecotropes

Dietary crude protein levels

\begin{tabular}{lcccc} 
Proximate composition & $12 \%$ & $15 \%$ & $18 \%$ & SEM \\
\hline Dry matter (\%) & $30.58^{\mathrm{b}}$ & $30.86^{\mathrm{b}}$ & $32.86^{\mathrm{a}}$ & 0.19 \\
Crude Protein (\%) & $31.45^{\mathrm{b}}$ & $31.57^{\mathrm{b}}$ & $33.03^{\mathrm{a}}$ & 0.12 \\
Crude Fibre (\%) & 15.31 & 15.54 & 15.80 & 0.52 \\
Ash (\%) & $9.12^{\mathrm{b}}$ & $9.26^{\mathrm{b}}$ & $10.60^{\mathrm{a}}$ & 0.02 \\
Ether extract (\%) & $2.93^{\mathrm{b}}$ & $3.00^{\mathrm{b}}$ & $4.20^{\mathrm{a}}$ & 0.03 \\
\hline ab Means along the same row with different superscripts are significantly $(\mathrm{P}<0.05)$ different \\
SEM: Standard error of mean
\end{tabular}

metabolism is greater in rabbits on a poor diet that is deficient in amino acid than with higher protein content. Takahashi and Sakaguchi (2002), also found that the prevention of coprophagy in guinea pig, lowered nitrogen retention and faecal concentration. Caecotropedeprived rabbits fed diets containing 18\% CP and $\mathrm{CC}$ rabbits fed diets containing $15 \% \mathrm{CP}$ recorded similar values for percentage nitrogen absorbed and retained. This observation suggests a cushioning of the effect caecotrope deprivation following increasing dietary crude protein levels.

\section{Characterization of Caecal Fermentation}

The practice of caecotrophy and dietary crude protein level (Table 4) showed significant $(\mathrm{P}<0.05)$ effects on total volatile fatty acid, propionate, ammonia nitrogen production, caecal $\mathrm{pH}$, acetate and butyrate production and propionate-butyrate ratio. An increase in VFA production and molar proportion was recorded following increasing levels of dietary crude protein and practice of caecotrophy. This may be due to the fact that caecotropes contains bacteria (hydrolytic species) which are involved in the breaking down of complex polymers to smaller compounds (monosaccharides, amino acids, e.t.c.) which are then converted to energy sources (VFA). Increasing dietary protein levels also increased $(\mathrm{P}<0.05)$ the amount of substrate used by caecal bacteria for fermentative activities. The highest molar proportion of VFA seen in $\mathrm{CC}$ rabbits fed diet containing 18\% CP may also be linked to increase levels of available substrates (dietary protein) for fermentation (de Blas, 2013). The caecal pH and ammonia concentration, were similar to those previously reported by Kimsé et al. (2012). Compared to rabbits on other treatments, $\mathrm{CC}$ rabbits on $18 \% \mathrm{CP}$ had the highest $(\mathrm{P}<0.05)$ values for $\mathrm{pH}$ and ammonia Nitrogen while those in the same group fed diets containing $15 \% \mathrm{CP}$ had the lowest $(\mathrm{P}<0.05)$ values. This observation may be due to the influence of caecotrophy and dietary protein levels on the rabbit cæcal ecosystem (Kimsé et al. 2012).

\section{Caecal Bacteria}

Table 5 shows the different types of bacteria isolated from the caecum of the rabbits fed experimental diets and population counts. The result showed that total viable bacteria count significantly $(\mathrm{P}<0.05)$ increased following an increase in dietary CP level and caecotrope consumption. Highest population count observed caecotrope-deprived rabbits fed diet containing $12 \% \mathrm{CP}$ may be due to proliferation of pathogenic organisms such as Clostridium perfinges in the caecum. This may also explain the higher mortality rate seen in this group of rabbits.

Predominant bacterial community seen across treatment groups were firmicutes (Ruminococcus, Clostridium, Streptococcus) and Bacteroidetes (Bacteroides). This is consistent with the findings of Combes et al. (2011) and Zhu et al. (2015). Firmicutes have their importance as a commensal in gastrointestinal health and have been described as the most abundant phylum in the gastrointestinal flora of most healthy mammal. The caecal bacteria of the rabbit change and adapt rapidly to reach a new equilibrium in response to nutrition (Michelland et al., 2011: Vantus et al.. 2014). Since caecotropes are a source of nutrients, the variety of bacterial organisms isolated from the caecum of caecotrope consuming and caecotrope deprived rabbits on diets containing varying levels of crude protein may imply that, caecotrophic behaviours 


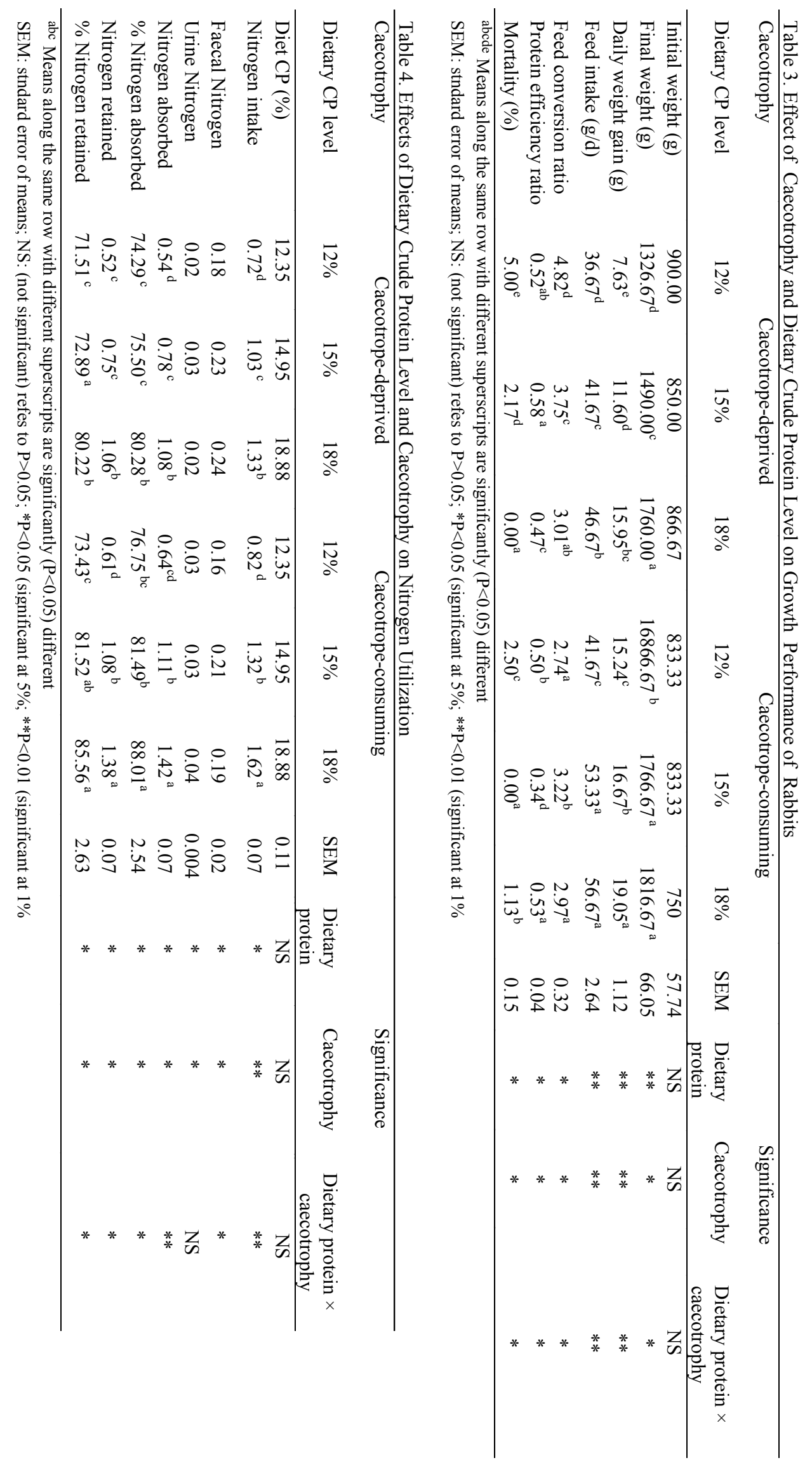




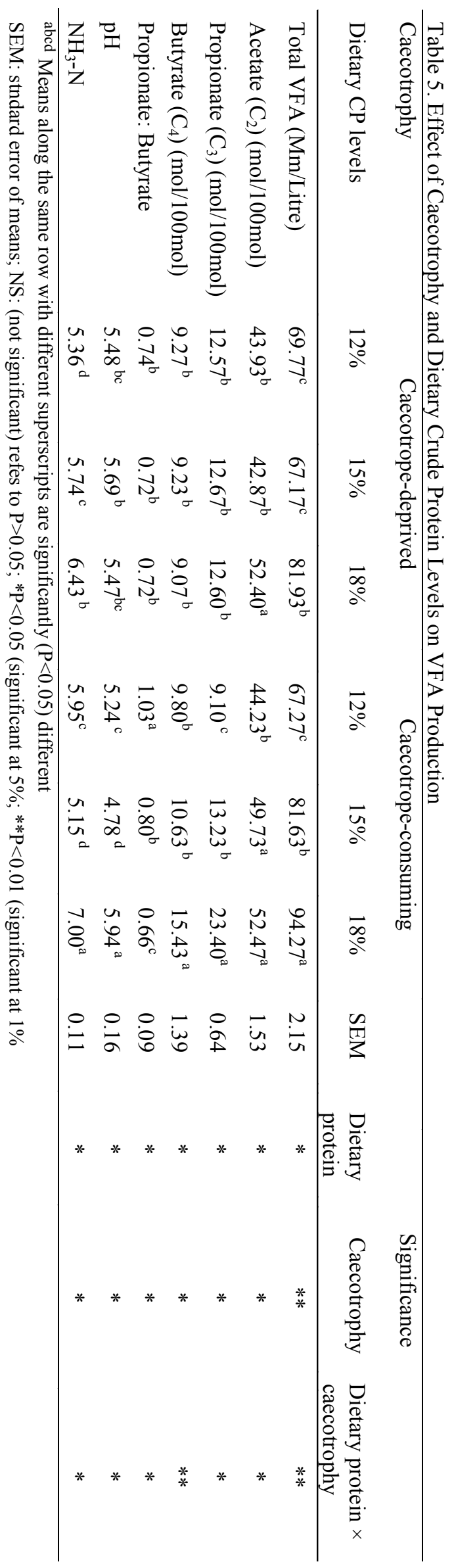


and dietary protein results in the proliferation of different types of bacteria in the gut. The activity of diverse bacteria present in caecum and soft faeces of rabbits has a great impact on the overall health status and growth performance of the rabbits as well as imparts on the digestion process in the animals (Combes et al. 2013: Kylie 2018). Ureolytic bacteria (Ruminococcus albus, Bacteroide ruminicola) are responsible for hydrolying urea in the caecum and play important roles in the nitrogen metabolism of the host (Cheng and Cord-Ruwisch, 2013). Lactobaccilus acidophilus isolated from the caecum of caecotrope consuming rabbits fed diets containing $12 \% \mathrm{CP}$ is rarely isolated from the caecum of rabbits. It helps to stimulate immune function by aiding gut microflora in via the production of lactic acid which aids normal bacteria and kills pathogenic bacteria (e.g. E. coli) (Fijan, 2014). This observation may suggest that caecotrophy is a form of adaptation, during times when diets are low in crude protein.

\section{CONCLUSION}

The observation of the current study suggest that it is unnecessary to feed caecotrope consuming rabbit in excess of their required $\mathrm{CP}$ levels $(15 \%)$ as this level is considered optimum for the rabbit nutrition. However, increasing dietary CP level attenuated the detrimental effects of caecotrope deprivation on the growth performance, caecal fermentation and gut bacteria.. Therefore, caecotrope consumption is a form of adaptation particularly in times of nutritional adversities such as when diet is low in CP.

\section{REFERENCES}

Association of Official Analytical Chemist (AOAC). 2005.. Official Methods of Analysis, $18^{\text {th }}$ edition, Washington DC.

Belenguer, A., J. Balcells, J. A. Guada, M. Decoux and E. Milne. 2005. Protein recycling in growing rabbits: contribution of microbial lysine to amino acid metabolism. Br. J. Nutr. 94:763-770.

Chaney, A.L. and E. P. Marbach. 1962. Modified reagents for determination of urea and ammonia. Clin. Chem. 8: 131-143.

Cheng, L. and R. Cord-Ruwisch. 2013. Selective enrichment and production of highly urease 565 active bacteria by non-sterile (open) chemostat culture. J. Ind. Microbiol.
Biotechnol. 566 (40):1095-1104.

Combes, S., R. J. Michelland, V. Monteils, L. Cauquil, V. Soulié, N. U. Tran, T. Gidenne, and L. Fortun-Lamothe. 2011. Postnatal development of the rabbit caecal microbiota composition and activity. FEMS Microbiol. Ecol. 77:680-689.

Combes, S., L. Fortun-Lamothe, L. Cauquil, and T. Gidenne. 2013. Engineering the rabbit digestive ecosystem to improve digestive health and efficacy. Animal 7 (9): 1429 1439.

de Blas, C. and G. G. Mateos. 2010. Feed formulation. In: Nutrition of the rabbit - 2nd edition. de Blas, C.; Wiseman, J. (Eds). CAB International, UK.

de Blas, C. 2013. Nutritional impact on health and performance in intensively reared rabbits. Animal, 7(1) : 102-111.

Fijan, S. 2014. Microorganisms with claimed probiotic properties: an overview of recent literature. Int. J. Environ. Res. Public Health. 11(5): 4745-4767.

Garcia, J., T. Gidenne, L. Falcao-E-Cunha, and C. deBlas. 2002. Identification of the main factors that influence caecal fermentation traits in growing rabbits. Anim. Res. 51:165-173.

Gidenne, T. and A. Lapanouse. 2000. Technical note: The measurement of soft faeces production is affected by the type of collar. World Rabbit Sci. 8 (1): 41-42.

Goto, Y., Y. Kurashima, and H. Kiyono. 2015. Roles of the gut mucosal immune system in symbiosis and immunity. (Rinshō Ketsueki) Jpn. J. Clin. Hematol. 56 (10): $2205-$ 2212.

Heinken, A., S. Sahoo, R. M. T. Fleming, and I. Thiele. 2013. Systems-level characterization of a host-microbe metabolic symbiosis in the mammalian gut. Gut Microbes. 4 (1): 28-40.

Jègsai, J., M. Teleki, and B. Juhàsz. 1985. Effect of caecotrophy on protein and amino acid metabolism of angora rabbits. Acta. Vet. Hun. 33: 51-57.

Kimsé, M., S. Combes, L. Cauquil, L. FortunLamothe, C. Bayourthe, and T. Gidenne. 2012. Impact of a dietary fiber deficiency on the cæcal ecosystem of the young rabbit. Modulation by yeast probiotics. World Rabbit Science Association Proceedings 10th World Rabbit Congress - September 3 - 6, Sharm El- Sheikh -Egypt, 519 - 523. 
Kujawinski, D. 2012. Gross Me Out: Why Rabbits Eat Poop and Other Gross Facts about Pets. Nsta Recommends Capstone Press; Arlington, VA, USA.

Kylie, J., J. S. Weese, and P. V. Turner. 2018. Comparison of the fecal microbiota of domestic commercial meat, laboratory, companion, and shelter rabbits (Oryctolagus cuniculi) BMC Vet. Res. 14 (1):143.

Meredith, A. 2011. Rabbit nutrition - An overview. Ir. Vet. J. 64(3): 160-164.

Michelland, R., S. Combes, V. Monteils, L. Cauquil, T. Gidenne, and L. FortunLamothe. 2011. Rapid adaptation of the bacterial community in the growing rabbit cæcum after a change of dietary fibre supply. Animal 5(11): 1761-1768.

National Research Council (NRC) 2011. Guide for the care and use of laboratory animals, 8th edition. National Academy Press, Washington DC, USA.

Phiny, C. and L. Kaensombath. 2006. Effect on feed intake and growth of depriving rabbits access to soft faeces, Livest. Res. Rural Dev. 18 (34). Retrieved from http:// www.cipav.org.co//rrd//rrd18/3/ phin18034.htm

Rodríguez-Romero, N., L. Abecia, M. Fondevila, and J. Balcells. 2011. Effects of level of insoluble and soluble fibre in diets for growing rabbits on caecal digestibility, nitrogen recycling and in vitro fermentation.: World Rabbit Sci. 19: 85 - 94.

Salami, S.A., O. A. Isah, R. Y. Aderinboye, L. O. Ajayi, and S. Ashi. 2021. Impact of caecotrophy on the performance, nutrient digestibility and blood parameters of growing rabbits. Nig. J. Anim. Prod. 48 (2): 140 $-147$.
Samuel, M., S. Sagarthewan, J. Thomas, and. G. Mathen. 1997. An HPLC method for estimation of volatile fatty acids of ruminal fluid. Indian J. Anim, Sci. 69:805-807.

Statistical Analysis System (SAS), 2004. SAS software package, version 9.1. SAS Institute Inc., Cary, NC, USA.

Takahashi, Y. and E. Sakaguchi. 2002. Significance of corprophagy in nitrogen utilization in the guinea pig. Sci. Links. 26: 7176.

Tham, H.T. and P. Udén. 2013. Effect of water hyacinth (Eichhornia crassipes) silage on intake and nutrient digestibility in cattle fed rice straw and cottonseed cake. Asian Australas. J. Anim. Sci. 26 (5): 646-653.

Vántus, V.B., M. A. Kovács, and A. ZSolnai. 2014. The rabbit caecal microbiota: development, composition and its role in the prevention of digestive diseases; A review: on recent literature in the light of molecular genetic methods. Acta Agra Kaposváriensis. 18 (1): 55-65.

Villamide, M.J., N. Nicodemus, M. J. Fraga, and R. Carabaño. 2010. Protein digestion. In: Nutrition of the rabbit (2nd Ed.). C. de Blas, J. Wiseman (Eds.), CABI, Wallingford, UK, pp.39-55.

Wang, Y., H. Xu, G. Sun, M. Xue, S. Sun, T. Huang, J. Zhou, J. J. Loor, and M. Li. 2019. Transcriptome analysis of the effects of fasting caecotrophy on hepatic lipid metabolism in New Zealand Rabbits. Animals. 9 (9): 648.

Zhu, Y., Wang, C. and Li, F. 2015. Impact of dietary fiber/starch ratio in shaping caecal microbiota in rabbits. Can J. Microbiol. 61: 771-784. 